\title{
Innovation in deep housing retrofit in the United Kingdom: The role of situated creativity in transforming practice.
}

\section{Robert Lowe \& Lai Fong Chiu}

\author{
"The realm of the practical, is the region of change, and change is always contingent; it has in it \\ an element of chance that cannot be eliminated."[1]
}

\section{Introduction}

The UK housing stock is seen as being amongst the least energy and carbon-efficient in Europe [2, 3]. Over half (57\%) of the 23.2 million homes in England [4] were built before 1965, when a basic level of thermal insulation was first required by the Building Regulations [5]. Improving energy efficiency through new construction is slow. Since 1991, the rate of construction of new homes has amounted to less than $0.5 \%$ of the stock per year, with demolition an order of magnitude lower still; most new build therefore adds to, rather than replaces existing dwellings. Retrofit of the existing housing stock is therefore unavoidable as part of any strategy for improving energy efficiency and reducing carbon emissions $[3,6,7]$.

The easier retrofit opportunities - loft insulation, insulation of cavity walls, replacement of single glazing, retrofitting of condensing boilers - have, to a large extent, already been taken up [8]. This means that further improvements in energy and carbon performance will need to come, in the main, from more expensive and technically challenging measures such as external wall insulation, airtightness coupled with efficient ventilation systems and low carbon heating systems such as heat pumps, coupled with decarbonisation of energy supply $[9,10,11]$. Coordinated packages of such measures, applied to individual dwellings, are often referred to as deep retrofit. In 2009 the UK's Technology Strategy Board (TSB) launched the Retrofit for the Future Programme (RftF) to develop the UK construction industry's capability for deep retrofit and innovation, and to provide a test-bed for the industry's response to the Green Deal, which was due to follow in 2013. Eighty-six exemplar projects (all in social housing) were selected for realisation on the basis of detailed design proposals submitted in an open competition. In order to achieve a deeper understanding of the variability of retrofit processes and performance outcomes in RftF retrofits, the authors were commissioned to undertake the FLASH (Facilitating Learning and Sharing) Project, based on a series of ten case studies drawn from these eighty-six exemplars.

The overall aim of this paper is to present insights into the genesis of innovation at work in retrofit, by reflecting on the experiences of project teams (PTs) that were involved in the FLASH Project. To this end, we begin by delineating the theoretical groundings for the paper. This is then followed by an outline of the research design and methods of the FLASH project. Finally, the analysis and findings of this inquiry are presented and their implications for research and practice are discussed. 


\section{The genesis of innovation}

In a review of the literature on innovation, Baregheh et al. identified 60 definitions of innovation from a variety of academic disciplines [12]. Thirteen of these definitions emerged from disciplines of technology, science and engineering alone. While this multiplicity of perspectives on "innovation" allows analysis of the phenomenon according to multiple attributes (nature, types, stages, social context, means/resources and aims), the mechanism by which innovation occurs, the question of where the new idea comes from, of how and under what circumstances it actually happens, has remained elusive.

This reticence can also be found in the standard, early reference on innovation, Everett Rogers' Diffusion of Innovations (DoI) Theory. As the title suggests, this focuses not on the genesis of innovations, but on how innovations are subsequently taken up [13 p12]. In a similar vein, one can detect in recent policy documents a focus on the adoption of ideas and the deployment of techniques, with little or no acknowledgement of the nature of or need for creativity throughout the adoption process $[14,15]$. Without such acknowledgement, and in the absence of understanding of the situational, organisational and regulatory contexts in which techniques are applied, little light is shed on the 'how' of innovation.

\section{Philosophical stance}

Attempts to understand energy performance of buildings by application of post-occupancy and building performance evaluation methods (POE \& BPE) has a long history $[16,17,18]$. This kind of research is usually carried out by engineers, building physicists, architects or other building professionals. While physical scientists often take their ontological and epistemological assumptions for granted and, largely ignoring social factors, see little need for theories other than thermodynamics, materials science and Newtonian mechanics to understand how buildings work, the converse is true for social scientists who often ignore the physical substrate of social actions in their empirical investigations. In the last decade, the authors have developed a socio-technical approach towards BPE and POE which integrates physical and social knowledge based on an ontological commitment that building performance is a socio-technical phenomenon, the understanding of which requires multi-disciplinary input $[19,20]$. To achieve this requires explicit adoption of a philosophical stance which both physical and social scientists can share.

For its philosophical and theoretical inspiration, the FLASH project drew heavily on Social Practice Theory in the sociological tradition, and on the contribution made by the American Pragmatists, Charles S. Pierce, Williams James, George Herbert Mead, and John Dewey, in the late $19^{\text {th }}$ and $20^{\text {th }}$ Centuries [21]. Dewey, in particular held that creativity emerged from tensions between goals and constraints. Such tensions tend to manifest themselves as problems, the appropriate formulation of which is the key to their solution. Since the RtfF programme set the construction industry the goal of innovating to achieve deep reductions in energy demand, it is, in this light, not unreasonable to look to the FLASH project for evidence and insight into the creative processes at work in retrofit. 
If philosophy is a way to help us think, the philosophy of Pragmatism appears to provide a way for the community of researchers to think differently. Pragmatism gives primacy to both practice and experience in how we know what we know; knowledge is less about "absolute truth" and more about "practical or functional truth" that aids actions in the world [22]. Pragmatists assume that the common and practical purpose of research is "problem solving" rather than theorising or empirical testing of physical or social theories for their own sake. The Pragmatists' approach to problem solving is through an ecological perspective which emphasises the importance of grounding problem solving in concrete situations. Creativity emerges, in problem solving, as actors reflect on their knowledge and experiences in-action and on-action [23]. Joas coined the term "situated creativity" to refer to this:

Actors confront problems whether they want to or not; the solution to these problems, however, is not clearly prescribed beforehand by reality, but calls for creativity and brings something objectively new into the world. [21 p.4]

This proposition appears to delineate the underlying causal mechanism of innovation that can tell us "why" creativity is needed, "how" it occurs, and "where" to look to see it. The next section of this paper will set out "how" to look.

\section{The pragmatist's socio-technical conceptual framework}

The multi-disciplinary nature of our research has motivated us to build a conceptual framework and methods beyond any single discipline [18, 19], a theoretical move that resonates with other researchers in this field [e.g. 24]. Social Practice Theory (SPT), a construct that encompasses materiality and human actions, provides a starting point. This is exemplified by Schatzki's formulation of social practices, such as cooking, voting and banking (and retrofitting), as "organised constellation[s] of actions", where actions are "bodily doings and sayings" [25 p.89, 26 p.70-72] that not only have material (technology) but also mental (practical understanding or knowhow), and social (explicit and tacit rules) substrates. Schatzki sees practices as directed towards goals within a structure of motivation and meanings (teleoaffectivity) [26 p.71]. Unlike other social practice theorists, Schatzki asserts that the organisation of social practices "should not be conceived as regularities, but instead as arrangements of people, artifacts and things" [27 p.15], with four theoretical components, teleo-affective structures, practical understanding, rules, and entities ${ }^{1}$,

\footnotetext{
${ }^{1}$ Practical understanding refers to know-how associated with activities, practical knowledge and actions. These include goals, key problems, problem-solving strategies and solutions, design, tacit knowledge and testing procedures.

Rules refer to institutional knowledge and procedures (social and technical) that enable and coordinate practices.

Teleo-affective structures refer to the purpose and affective aspects of a practice and how these are structured to influence the motivation and direction of activities.

Entities comprise living and non-living entities with human/man made and non-human and nonmanmade entities as another dimension. People are human and living entities; Artefacts are man-
} 
which should be conceived as mutually co-constitutive. While SPT has been useful in the reconceptualization of conventional POE, there are two significant limitations to its application to the study of innovation. These are delineated below.

\subsection{Limitation 1 - the erasure of the physical}

Despite Schatzki's assertion that "A theory of X is a general and abstract account of X" [27 p.12 emphasis added], a variety of practice theories has emerged in the energy and buildings research arena as approaches to offering social explanations for energy consumption e.g. [28-32], through the study of heating/cooling practices e.g. [33,34], and thermal comfort of occupants in their dwellings e.g. [35-38]. While, with a few exceptions [20, 39, 40], the afore-mentioned studies formally acknowledge the material aspect of social practice, they seldom integrate the physical into methods for empirical investigation. For example, while heating and cooling may be formally acknowledged as materially mediated nexuses of activity, physical/material conditions relating to heating and ventilation systems and how these systems are configured and arranged within the fabric of dwellings in ways that may influence occupants' heating and cooling activities and/or impinge on technical performance, are, in practice, often ignored. Moreover, by re-labelling the research category "dwelling" as "home", and imbuing it with social meanings such as "a special kind of place", researchers can conveniently shift the focus from physical conditions of dwellings such as the basic construction, orientation, configuration of systems, temperature, humidity and condensation, onto feelings and social relations that constitute a "sense of place" or "homeliness" (e.g. [41]). While this approach draws attention to the indirect role of energy consumption in people's everyday "home making practices", it provides little insight into how retrofit is done, how it improves physical living conditions, or the role of technical innovation within it. It is obvious from the foregoing that this tendency is inconsistent with theoretical formulations of SPT. But more importantly, it has been demonstrated that only by explicitly accounting for the co-constituting elements by which practices are instantiated [e.g. 18, 20,40,42], can one begin to investigate the underlying mechanisms by which practices persist or change. Thus, technology is unavoidably part of the study of retrofit innovation.

\subsection{Limitation 2 - the erasure of the human mind}

Attempts to resolve the omission of the physical were first articulated by the posthumanist theorists, e.g. [43, 44, 27 p.21-22]. Premised upon "the mutual co-constitution of material and human", Pickering attempted to address this by proposing to study the interactions between the material, scientific theory and social action and institutions. His accounts of the synthetic dye industry, railroads, and post-world World II cybernetics provide paradigmatic examples of "key sites of encounter between the material and the human" [45 p.172-183]. While Pickering's theoretical stance purports to encompass the role of human agency in technological change, his empirical research was entirely historical. More importantly, while it appeared to transcend the duality of agency and structure that obsesses the sociological tradition, it effectively erased the role of the human mind. Schatzki asserts that this is true across the practice theory literature: "Practices,

made and non-living entities; organisms are non-human and non-man made entities; and things are non-human/non-man made and non-living entities. 
in sum, displace mind as the central phenomenon in human life" [27 p.11].

With the above limitations, it is evident that, while SPT is useful as a framework to account for the co-constituted nature of retrofit practices, the framework by itself is insufficient to account for how practices change and new practices emerge, and the underlying mechanisms of innovation remain elusive. The Pragmatists' insight that humans are problem solvers appears to offer a way to restore the human mind from its erasure from SPT. For the Pragmatists, humans solve problems by first enacting routinised action i.e. habitual responses acquired through learned experience, and only when such routinised action fails to achieve the desired outcome in a new situation, does human creativity come into play. At this juncture, actors begin to imagine possible solutions, opening up their sense of practice to creative and inventive processes of search and brainstorming, thinking outside-the-box, taking ambiguity as generative not paralyzing, probing and reframing the problem [46 p.2]. The alternation between habit and creativity that can be observed in human responses to problematic situations is the Pragmatist's corollary claim [1 p.42] - and indeed, Gross [47] has argued that this alternation is the underlying mechanism that shapes, maintains and reshapes social life more broadly ${ }^{2}$. Combining SPT and the concept of "situated creativity" into a single conceptual frame offers us both a heuristic device for analysing retrofit practices as a complex socio-technical phenomenon, and helps to focus our attention on the context of, and activities associated with problem solving as the key to researching the genesis of innovation in retrofit.

\section{Research design \& methods}

Our socio-technical conceptual frame helped us to formulate an explicit research design that set the boundaries, levels and units for the overall investigation and analysis of cases in the FLASH project. An extensive description of this research design has been published in a recent methodological paper [19] and will not be repeated here. However, key features of the design and methods are outlined, to background the reflections of the seven project teams (PTs), focussing on their responses to problem solving. These reflections, presented here at some length, are a window into the phenomenon of innovation in the context of retrofit.

\subsection{Sampling the socio-technical site of retrofit}

The FLASH Project involved ten dwellings of diverse typology, selected for retrofit by seven project teams. Six of the seven PTs comprised a registered social landlord (RSL), an architect, mechanical and electrical consultants (M\&E), energy and other consultants, and contractors. Five PTs were led by an RSL, the remaining two by an architect. The structure and composition of the respective households (from two single-person households to a variety of family groups) and the composition of the PTs themselves, provided social contexts that prefigured strategic actions and social

2 Although the above discussion sets out to ground the paper in the pragmatist philosophical tradition, it is worth noting that understanding of the roots of creativity in the alternation between habit and creativity has been enriched by a number of other disciplinary perspectives, including philosophy, economics, history of science, cognitive science and artificial intelligence [48 p.61, 4953]. Implicit or explicit in all of this literature is the idea that creativity emerges from the tension between goals and constraints. 
interactions in the course of retrofit.

A summary of the socio-technical sites is presented in Table 1 below.

\begin{tabular}{|c|c|c|c|c|c|c|c|c|}
\hline Case & A & B1-3 & $\mathrm{C}$ & $\mathbf{D}^{*}$ & E & F & G & $\mathbf{H}^{*}$ \\
\hline \multicolumn{9}{|c|}{ Physical arrangements, pre-retrofit } \\
\hline $\begin{array}{l}\text { Dwelling } \\
\text { type and } \\
\text { approx. } \\
\text { year of } \\
\text { construct- } \\
\text { ion }\end{array}$ & $\begin{array}{l}\text { Three-bed } \\
\text { terrace. } \\
1992\end{array}$ & $\begin{array}{l}\text { Three- } \\
\text { bed } \\
\text { terrace. } \\
\text { 1970s }\end{array}$ & $\begin{array}{l}\text { Three-bed } \\
\text { terrace, } \\
\text { modernis- } \\
\text { ed with } \\
\text { central } \\
\text { heating two } \\
\text { years prior } \\
\text { to retrofit. } \\
\text { Victorian }\end{array}$ & $\begin{array}{l}\text { Four-bed } \\
\text { mid-terrace } \\
\text { con- } \\
\text { struction. } \\
1940-50 \text { 's }\end{array}$ & $\begin{array}{l}\text { Two- bed } \\
\text { mid- } \\
\text { terrace. Pre- } \\
1919 \text {, in a } \\
\text { con- } \\
\text { servation } \\
\text { area }\end{array}$ & $\begin{array}{l}\text { Four-bed } \\
\text { semi- } \\
\text { detached. } \\
\text { 1960s }\end{array}$ & $\begin{array}{l}\text { Four-bed } \\
\text { end-terrace. } \\
\text { Late } \\
\text { Victorian }\end{array}$ & $\begin{array}{l}\text { Three-bed } \\
\text { semi- } \\
\text { detached } \\
\text { (originally } \\
\text { built as } \\
\text { detached). } \\
\text { Early 1900s }\end{array}$ \\
\hline $\begin{array}{l}\text { Gross floor } \\
\text { area }\end{array}$ & $83.7 \mathrm{~m}^{2}$ & $95 \mathrm{~m}^{2}$ & $87.4 \mathrm{~m}^{2}$ & $100 \mathrm{~m}^{2}$ & $80 \mathrm{~m}^{2}$ & $130 \mathrm{~m}^{2}$ & $76.8 \mathrm{~m}^{2}$ & $83.6 \mathrm{~m}^{2}$ \\
\hline $\begin{array}{l}\text { Wall con- } \\
\text { struction }\end{array}$ & Brick cavity & wall ----- & $\begin{array}{l}\text { Solid brick } \\
\text { wall }\end{array}$ & $\begin{array}{l}\text { Rendered } \\
\text { solid brick } \\
\text { wall }\end{array}$ & $\begin{array}{l}\text { Solid brick } \\
\text { wall }\end{array}$ & $\begin{array}{l}\text { Brick cavity } \\
\text { wall }\end{array}$ & $\begin{array}{l}\text { Solid brick } \\
\text { wall }\end{array}$ & $\begin{array}{l}\text { Solid brick } \\
\text { wall }\end{array}$ \\
\hline $\begin{array}{l}\text { Ground } \\
\text { floor con- } \\
\text { struction }\end{array}$ & $\begin{array}{l}\text { Suspended } \\
\text { timber floor }\end{array}$ & $\begin{array}{l}\text { Solid } \\
\text { concrete } \\
\text { floor }\end{array}$ & Suspended $t$ & mber floor ---- & ----------- & -------------- & $\begin{array}{l}\text { Mix of solid } \\
\text { and } \\
\text { suspended } \\
\text { floors }\end{array}$ & $\begin{array}{l}\text { Suspended } \\
\text { floor }\end{array}$ \\
\hline Glazing & Single & Double & Single & Single & Single & Single & Single & Single \\
\hline \multicolumn{9}{|c|}{ Social arrangements } \\
\hline $\begin{array}{l}\text { Project } \\
\text { team }\end{array}$ & $\begin{array}{l}\text { Architect } \\
\text { led }\end{array}$ & $\begin{array}{l}\text { RSL } \\
\text { led }\end{array}$ & RSL led & $\begin{array}{l}\text { Architect } \\
\text { led }\end{array}$ & RSL led & RSL led & RSL led & $\begin{array}{l}\text { Architect } \\
\text { led }\end{array}$ \\
\hline $\begin{array}{l}\text { Household } \\
\text { com- } \\
\text { position }\end{array}$ & $\begin{array}{l}\text { Single } \\
\text { mother } \\
\text { with } 2 \\
\text { children }\end{array}$ & $\begin{array}{l}\text { Family of } \\
4,4, \& 3\end{array}$ & $\begin{array}{l}\text { Elderly } \\
\text { single } \\
\text { woman }\end{array}$ & $\begin{array}{l}\text { BME } \\
\text { family of } 8\end{array}$ & Single male & Family of 7 & $\begin{array}{l}\text { BME family } \\
\text { of } 5\end{array}$ & $\begin{array}{l}\text { Elderly } \\
\text { couple }\end{array}$ \\
\hline
\end{tabular}

Table 1. Summary of socio-technical arrangements - dwellings, project teams, and households.

Note that B1-3 were three dwellings in a terrace of four, all of which were retrofitted by a single PT (PT-B). Dwellings D\&H were also retrofitted by a single PT (PT-D\&H).

Key: BME=black or minority ethnic. RSL=registered social landlord.

\subsection{Data frame and responsible disciplines}

With boundaries, levels and units set, the initial set of "variables of interest" could be determined. These were broadly grouped under the following 5 headings, with the lead discipline(s) within the multi-disciplinary research team indicated in brackets: 
1) Physical data [building physicist, architects] i.e. dwelling type, year of construction, energy efficiency measures installed. These data were collected by Databuild, EST's research subcontractor. They were available through request.

2) Monitoring data [architects, monitoring technician] i.e. gas/electricity consumption, internal temperature, relative humidity etc. were collected by University of Reading and were available to researchers through a secure EST portal.

3) Social data [social scientist] - i.e. occupants' and project teams' experiences were captured by semi-structured interviews with walk-throughs, and reflective focus group interviews respectively.

4) Visual data [social scientist, architects] i.e. photographs taken of construction and equipment inside and outside of dwelling.

5) Documentary data such as architectural drawings and site plans [architects \& building physicist] were also downloaded from the EST portal.

\subsection{The reflective focus group method}

The primary tool for collecting data on retrofitting practices from Project Teams was the reflective focus group method. This method has its origin in social research, with its philosophical roots in Pragmatism. According to Dewey, reflection is a necessary component of knowledge production through experience. The reflective focus group has cognitive, intuitive, affective, and dialogic aspects [54 p.5].

Focus group discussions were structured to cover the four components of SPT. These are PTs' motivation and purpose (teleo-affectivity) for their participation in the RftF programme; their design intent (technologies) and experiences (practical understanding and rules) in the process. Specific care was taken to elicit any problems that PTs may have encountered in implementing their intended retrofit strategy. Documents such as site plans and photographs were presented as stimuli to trigger memories and facilitate dialogue. Each focus group lasted for approximately two-and-ahalf hours. All discussions were audiotaped and transcribed verbatim for analysis.

\subsection{Analysis}

Within the multi-disciplinary team, analysis started by capturing occupants' and PTs' experiences and corroborating them with physical observations and monitoring data. This made it possible to piece together a picture of the retrofit strategy/design-intent, the process of implementation, and occupants' resulting experiences in each case, as well as problems encountered. In the course of analysis, we identified three specific issues where clarification of PTs' responses might help us to understand the genesis of innovation. These are: 1) radical change of design-intent of PTA; 2) malfunctioning of communal heating/ventilation system of PT-B1-3; and 3) the successes of PTD\&H in applying the Passivhaus approach (a combination of high levels of insulation, airtightness and MVHR). Three follow-on individual interviews with leading participants of PT-A, PT-B and PT-D\&H were also conducted. 


\section{Findings}

\subsection{Motivation and purpose (teleo-affectivity)}

It is clear that the experimental and competitive nature of the RftF programme had set the tone for those PTs that took part in the FLASH project. All PTs viewed their projects as providing research and learning opportunities and opportunities to gain practical experience in retrofitting to a high standard.

In the absence of baseline data, TSB's intention was that PTs would assess the energy and carbon performance of retrofits by comparing physical monitoring data with designed-based predictions based on a modified Standard Assessment Procedure (SAP) calculation. The goal of achieving an $80 \%$ carbon reduction was perceived as challenging and this had induced a sense of a technological adventure. For example:

As designers and architects (in the housing industry) we have an interest in seeing what exactly does it take to achieve an $80 \%$ reduction for the project and then feed that back into our other work. (PT-B)

The M\&E contractor of one of the PTs clearly felt that the aim of achieving an $80 \%$ reduction was made more challenging as they perceived it, because their own roles were subordinated to the "design intent" set by the architect and RSL.

Despite being aware of such constraints, the contractor was interested in the transition from current practice of simple and piecemeal thermal improvements to a more complex and integrated approach to retrofit, and in how to extend their practical knowledge, gained from new-build, to the existing stock in which conventional construction sequencing may be impossible, and a much more flexible approach might have to be adopted.

We're interested in... how it's impacted residents. A lot of the work we do is in occupied properties, so we need to understand how it [sequencing] works in occupied properties. And also, we're interested in...post occupancy evaluation. As an organisation we're looking at things like the Green Deal, and so we need an understanding of how these technologies are actually going to work in practice. Um, and then also, the costs and how we can scale up similar measures involved. (PT-B)

This contractor was keen to expose his workforce to learning about new retrofit technologies, in the expectation that a thriving market for them would emerge as a result of policies such as the Green Deal. He saw the gaining of first-hand experience through $\mathrm{RftF}$ as preparation for seizing new business opportunities ${ }^{3}$.

${ }^{3}$ Rosenow \& Eyre [55] and the National Audit Office [56] have presented informative analyses of the subsequent failure of the Green Deal. For the sector as a whole, the hoped-for business opportunities have, at the time of writing, so far not materialised. While this policy failure post- 
Some of the RSLs were motivated to experiment on how retrofit work could be applied at a scale larger than the single dwelling: in other words, to terraces, or blocks of apartments. For example, the RSL of PT-B deliberately selected a terrace of four dwellings, in an attempt to see whether there were significant economies from retrofitting at scale:

...so rather than spend $£ 150,000$ on doing one property, we wanted to see actually, if you were going to scale this up, what could you do with $£ 30-40,000$ a property. [...] we wanted to come up with a small, communal boiler system, a solution for small blocks of terraces. [That] is why we ended up with multiple properties. (RSL, PT-B)

\subsection{Retrofit strategies}

PTs used a variety of terms to describe their retrofit strategies: "Fabric first", "Insulate then Generate", "Passivhaus", and "Whole House". This diversity of terminology only partially obscures a significant overlap of approach. While efforts to reduce fabric losses and air leakage were common to all these projects, and all used natural gas ${ }^{4}$ as the main form of heating (complemented by solar water heating and, in Case E, by an exhaust air heat pump), there were significant variations amongst them in the choice and implementation of ventilation systems, together with a five-fold variation in target and achieved airtightness (see Table 2).

The sample dwellings spanned a wide range of forms, age and construction, and the detailed approaches to fabric insulation were similarly varied. PTs were asked to consider the physical and social constraints that had impeded the implementation of their strategies. This request revealed considerable socio-technical know-how and strategic thinking. For example, the RSL in PT-H recognised that dwellings that had heritage value and/or cavity walls were most likely to be problematic and were best avoided ${ }^{5}$. As the RSL remarked:

...[had we] pursued the alternative property that we initially considered, we almost certainly would have run into conservation area issues, which would have inhibited the ability to implement measures. [But] we didn't want to deliberately put obstacles in our path...we chose a property of relatively non-descriptive architectural merit, shall we say. It was a very standard 1950 's - sixties? fifties? - built, surprisingly as solid wall ${ }^{6}$.

dated the FLASH project and RftF Programme, it is likely to have affected the PTs in the years following RftF.

4 The whole terrace was connected to a gas main. Discussion of the future of the UK natural gas distribution system has largely post-dated the RftF Programme.

${ }^{5}$ Strategies to decarbonise heritage dwellings would probably need to focus more on decarbonisation of electricity and heat, and less on fabric.

${ }^{6}$ Though, not so surprising. While cavity wall construction had become standard across the North and West of England and Wales by the 1920s, in the drier and more sheltered Southeast of England, solid-walled construction persisted into the mid-50s. 


\begin{tabular}{|c|c|c|c|c|c|c|c|c|}
\hline Cases & B1-3 & F & G & E & $\mathrm{C}$ & $\mathbf{H}$ & D & A \\
\hline $\begin{array}{l}\text { Stated } \\
\text { retrofit } \\
\text { approach }\end{array}$ & fabric first & $\begin{array}{l}\text { insulate } \\
\text { then } \\
\text { generate }\end{array}$ & fabric first & $\begin{array}{l}\text { modified } \\
\text { Passivhaus }\end{array}$ & fabric first & Passivhaus & Passivhaus & $\begin{array}{l}\text { whole } \\
\text { house }\end{array}$ \\
\hline $\begin{array}{l}\text { Energy } \\
\text { efficiency } \\
\text { strategy }\end{array}$ & $\begin{array}{l}\text { EWI, AC, } \\
\text { CHS, whole } \\
\text { house } \\
\text { MVHR }\end{array}$ & $\begin{array}{l}\text { HPCF, } \\
\text { PIV }\end{array}$ & EWI, AC & $\begin{array}{l}\text { HWI } \\
\text { MEV+HP } \\
\text { inter- } \\
\text { mediate } \\
\text { leakage }\end{array}$ & $\begin{array}{l}\text { HWI } \\
\text { individual } \\
\text { vent. }\end{array}$ & $\begin{array}{l}\text { EWI, AC, } \\
\text { whole } \\
\text { house } \\
\text { MVHR }\end{array}$ & $\begin{array}{l}\text { EWI, AC, } \\
\text { whole } \\
\text { house } \\
\text { MVHR }\end{array}$ & $\begin{array}{l}\text { HWI, inter- } \\
\text { mediate } \\
\text { leakage, HV } \\
\text { (natural + } \\
\text { individual } \\
\text { MVHR) }\end{array}$ \\
\hline $\begin{array}{l}\text { Airtightness } \\
\text { pre-retrofit }\end{array}$ & no record & no record & 10.6 & 16.8 & 8.9 & 7.1 & 6 & 5.6 \\
\hline $\begin{array}{l}\text { Airtightness } \\
\text { target }\end{array}$ & 1 & 5 & no record & 5 & no record & $0.6-1.0 \mathrm{ac} / \mathrm{h}$ & 0.7 & 3 \\
\hline $\begin{array}{l}\text { Airtightness } \\
\text { achieved }\end{array}$ & no record & no record & 3.8 & 5.9 & 9.0 & 1.4 & 1.4 & no record \\
\hline
\end{tabular}

Table 2. Summary of retrofit strategies and energy efficiency measures applied.

Pre-retrofit airtightness, design and achieved airtightness, in units of $\mathrm{m}^{3} / \mathrm{m}^{2} / \mathrm{h}$ at 50 Pa unless stated otherwise. Note that dwellings are listed in order of occupant satisfaction [57].

Key:

$\mathrm{AC}=$ airtight construction

$\mathrm{CHS}=$ communal heating system

EWI= external wall insulation

$\mathrm{MEV}+\mathrm{HP}=$ continuous extract ventilation with exhaust air-heat recovery to hot water

$\mathrm{HPCF}=$ high performance cavity fill

$\mathrm{HV}=$ hybrid ventilation

HWI= hybrid wall insulation - e.g. external at the back, internal at the front

MVHR= mechanical ventilation heat recovery

$\mathrm{PIV}=$ positive input ventilation

Reflecting on how house $\mathrm{H}$ had been chosen for retrofitting, the RSL said that they first opted for houses with solid wall construction, so as to minimise techno-economic obstacles to implementing Passivhaus-level insulation, airtightness and heat recovery ventilation. Added to the criterion of choosing $\mathrm{H}$ as an experiment in Passivhaus retrofit, was the PT's hope of understanding how this might improve health amongst low-income occupants. The occupants of Case $\mathrm{H}$ were an elderly couple, one of whom suffered a chronic health condition. The RSL wanted to see whether there was 
"[a potential health] benefit [that might] demonstrate, perhaps to policy people, that such an approach is healthy to people."

In their original pre-retrofit state, the solid walls of dwellings $\mathrm{G}$ and $\mathrm{H}$ were part- or fully-rendered, and the houses were aesthetically and historically unremarkable. They therefore presented no aesthetic or practical obstacles to external insulation, a fact of which PTs took full advantage, specifying and adding up to $250 \mathrm{~mm}$ of external insulation. Following similar logic, the PTs of dwelling B, D G \& H adopted a fully-fledged Passivhaus fabric strategy, involving the reduction of wall $U$ values to around 0.14 , and roof $U$ values to around $0.08 \mathrm{~W} / \mathrm{m}^{2} \mathrm{~K}$. The original aim of the PT that undertook both $\mathrm{D}$ and $\mathrm{H}$, was to reduce air permeability to below $1 \mathrm{~m}^{3} / \mathrm{m}^{2} / \mathrm{h} @ 50 \mathrm{~Pa}$, by the formation of a continuous air barrier around the whole dwelling, and then to make use of mechanical ventilation with heat recovery (MVHR).

It therefore seems that for cases B, D, G and H, it was the retrofit strategy that determined which dwelling would be chosen for the competition, rather than the other way around. These dwellings were chosen so that the most energy efficient fabric strategy could be applied unproblematically to them.

A different strategy was adopted by PTs C, G, \& $\mathrm{E}^{7}$, of accepting somewhat higher $\mathrm{U}$ values and significantly higher target air leakage rates (typically, $5 \mathrm{~m}^{3} / \mathrm{m}^{2} / \mathrm{h} @ 50 \mathrm{~Pa}$ ). All four PTs used an insulation strategy that combined internal insulation at the front and external at the rear. This enabled the retention of the original front façade, at the cost of a relatively higher post-retrofit $U$ value at the front and additional complexity at junctions, the latter only partially offset by thicker (up to $250 \mathrm{~mm}$ ) insulation ${ }^{8}$ at the rear.

\subsection{Problems \& responses}

Despite the above-mentioned strategies, PTs' knowledge of and skill in applying fabric insulation was repeatedly tested in the retrofit process. How PTs dealt with some of the emergent problems is set out below.

A technical problem that confronted all of the PTs was how to minimise discontinuities in air barrier and thermal insulation layer (the thermal envelope) around the dwelling. This requires careful coordination at junctions:

- wall-to-roof (which also involves consideration of drainage);

- windows and doors with external walls;

- wall-to-wall (typically, front and back walls with party and/or side walls);

- external wall-to-ground or wall-to-ground floor.

7 Dwelling E was listed as Grade II, the second highest level in the UK system for recognising and protecting buildings with heritage value.

${ }^{8}$ External insulation enables thick and therefore relatively cheap insulants to be used while achieving low $\mathrm{U}$ values. 


\section{Response to occupants' requirements - Dwelling A}

In order to deal with a cavity walled, mid-terraced house, PT-A wanted to apply external insulation at both front and back, in conjunction with low air leakage and MVHR. But, confronted by the occupant's desire for their home not appear to "stand out" after retrofitting, for minimum disruption through, and after the retrofitting process, and for a ventilation strategy to accommodate smokers, PT-A switched instead to a strategy closer to that of PTs C, G, \& E. The result was an almost complete re-design, and the development and implementation of a highly innovative, whole-house strategy.

\section{Response to unexpected features of pre-retrofit construction - Dwelling D}

External insulation of all above-ground construction elements in principle makes all junctions referred to above easier to deal with. But a detailed survey may reveal features that require revision of this strategy. Case D, a three-storey, mid-terrace dwelling, was just such a case. In the focus group, the constructor in the PT-D reflected on how the problem was resolved.

Well as I said, the original intention was to take off the roof completely and then put a new insulated timber roof, which would allow the attic space to be part of the thermal envelope.

But it was quickly discovered that there were no party walls at roof level in the terrace of dwellings - just a continuous roof void 9 . This would have made insulating just one of the houses at roof slope level ineffective. The constructor continued:

Because we tried to minimise disruption, we looked at just insulating across the ceilings [...] It made it a lot simpler. We only needed to take off the lower, sort of five to six [tiles], maybe more actually $[\ldots]$ and because $[\ldots]$ one of the details we needed to get across was we've increased the size of the walls and so we needed to increase the roofs to go over the top of the walls and we suggested using a technique which is quite common in Germany, which is to actually add additional timbers to the edges of the eaves to extend those out over the external insulation. So, taking those [out] allowed us to [form tunnels at the eaves] ... externally the tunnels are over the roof, over the wall insulation but also work on the airtightness of the ceilings and how that connected back into the external wall.

The increased thickness of the wall also impacted on window positioning and fixings, which were challenges that the team had to overcome. PT-D spent considerable time developing their own technique to strap the new windows back to the existing masonry in a way that positioned them in the plane of the external insulation. The PT thought that with practice, this technique could be perfected and applied to other projects with greater efficiency:

\footnotetext{
9 Though it would be hard to make such a construction compliant with modern fire regulations, it is not that uncommon in older houses.
} 
We did sort of spend a lot of time [on the window] so I think the more you do it the more you understand. [...] If say there were 50 of these [dwellings], we could do a little bit of research and find out what's the best way to just strap the [window into place].

An additional problem was a pre-existing lean-to extension built out into an earlier outdoor toilet and garden shed. To avoid thermal bridging and to improve the thermal integrity of the whole dwelling, PT-D decided to rebuild the entire extension.

Integrating new materials and addressing existing regulatory requirements - Dwellings E and A PT-E recognised the socio-technical difficulty of insulating a ground floor of hybrid construction (a mix of suspended timber and concrete slab-on-ground) in a small late-Victorian dwelling. The problem was, not only that they had to insulate the floor without decanting the occupants, but also without damaging the gas pipe that ran beneath the existing floor. They overcame this by applying a layer of nanogel insulation to the top of the existing floor, thus raising the finished floor level. Pleased with their solution, the constructor remarked:

It was really good learning, you know, to try something new and different, looks like a good solution. And picking up the things that you have to do to make it work properly. And the gas could potentially kill anyone, it is a safety issue and what we would probably do next time is to think about solutions for sleeving that gas main in a ventilated pipe. So, what we thought as a simple idea could become a little bit more complicated but not much more complicated. Still a pretty good solution, but we need to work on the BBA ${ }^{10}$.

The approach of PT-A to insulating the ground floor was similar to that of PT-E, but provided a further example of the demands of retrofit colliding with existing regulation. PT-A said that they insulated the whole of the ground floor with evacuated panel insulation, with a floating floor on top, to avoid taking up the screed. This method raised the floor about $25 \mathrm{~mm}$, causing all doors to have to be refitted, and, to comply with the requirement of Approved Document $\mathrm{K}$ of the Building Regulations for England \& Wales for rise and going of each step to be consistent throughout a flight of steps, requiring adjustments to the stairs. The PT talked about having to "battle with Building Control" over the height of steps on the stairs. PT-A was aware from the outset that they would have to deal with this issue, and that interpretation of regulations might vary between different building control organisations. It is possible that a future review of Approved Document $\mathrm{K}$ could simplify similar retrofits by explicitly addressing this situation, and perhaps by setting out acceptable tolerances on stair dimensions. If the size of the retrofit market were to expand significantly, one might also imagine the marketing of packs of stair-height adjusters that would dramatically simplify the problem faced by PT-A.

${ }^{10}$ BBA, previously the British Board of Agrément, is one of the organisations responsible for certification of building materials and systems in the UK. 


\section{Choosing insulation strategies to minimise complexity - Dwellings B \& H}

In contrast, PTs for dwellings B (a terrace of houses) and H (a single detached solid walled house) avoided the problem of ground floor insulation altogether by continuing external insulation of external walls to below ground level. As noted earlier, this strategy is only possible where walls are being insulated externally, and illustrates the way that the reconfiguration of one element or aspect of dwelling's performance may constrain or enable approaches to other elements or aspects of performance.

Interactions between airtightness and ventilation strategy - Dwelling D

The carbon reduction goal of the RftF programme compelled PTs to go beyond what was required by current building regulations. Reflecting on the result of pressure testing, the representative of the architecture practice that led PT-D was animated and encouraged that their dwelling had achieved $1.6 \mathrm{~m}^{3} / \mathrm{m}^{2} / \mathrm{h}$, roughly a factor of 5 beyond existing regulation and practice. He remarked:

We wanted to get to 1.0 and [...] it would be really good to, I mean it's still 7 times better than building regulations, which is fantastic. But, there could be just something very minimal [...] it might be even just the adjustment of the door, and in some of the doors there's a little adjustment on the clip...

It has long been recognised that very energy efficient dwellings require the support of well controlled ventilation systems within an airtight building envelope to protect the building's fabric from moisture and to provide the occupants with healthy and comfortable conditions [58].

Several of the PTs were aware that choosing an appropriate combination of ventilation and airtightness strategy would improve energy efficiency. In airtight dwellings, Mechanical Ventilation Heat Recovery (MVHR) technology can save significant amounts of energy compared with other strategies - the principles are illustrated qualitatively in Figure 1. This shows that there is likely to be little to choose, in terms of $\mathrm{CO}_{2}$ emissions, between continuous Mechanical Extract Ventilation (MEV) systems and MVHR at air permeabilities around $5 \mathrm{~m}^{3} / \mathrm{m}^{2} / \mathrm{h} @ 50 \mathrm{~Pa}$. However, once this threshold is crossed, well designed, installed and commissioned MVHR systems allow steadily increasing energy benefits from air tightness. The graph also illustrates significant ranges of performance for both MVHR and MEV systems. This analysis frames the following observations on the ventilation systems implemented by the PTs.

Given the intention to retrofit the fabric of dwelling D to Passivhaus standard, PT-D's initial decision was to implement a ventilation strategy using triple glazed windows (which, in this configuration, would have had a nominal U-value of c.1.5 W/m² $\mathrm{K}$ ) as heat recovery devices ${ }^{11}$. This system in principle has the advantage of saving valuable space in small dwellings. However, its use in house D was abandoned because of supply chain availability. The architect explained:

11 Though the first author became aware of it in the 1980s, it appears that this technology emerged in Finland in the 1950s [60]. 
When we actually started the scheme, we were working with an engineer from [...], who was trying to trial a naturally ventilated Passivhaus approach using windows that had a kind of inbuilt heat recovery system, and that standard ventilation which would draw air out of the building $[\ldots]$, it turned out that the windows we were hoping to use hadn't really been manufactured successfully, except on a trial project in Poland [...] So, that kind of resulted in us moving back to a more traditional ventilation strategy. Looking at the numbers we realised that we also simply couldn't get the levels of energy efficiency from a naturally ventilated building as we could from the small power requirement of the pinnacle [MVHR] system.

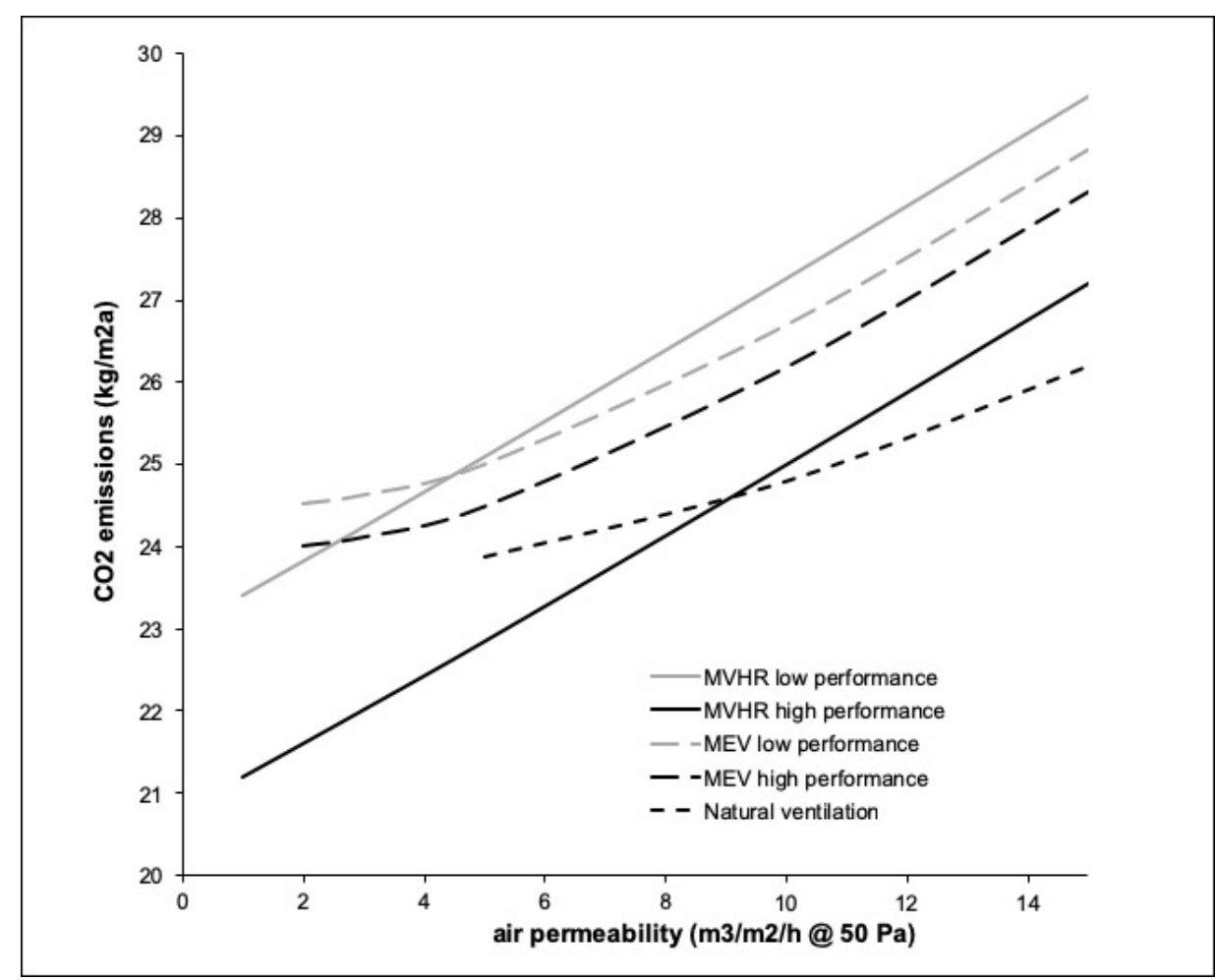

Figure 1. Impact of air leakage on predicted $\mathrm{CO}_{2}$ emissions for three ventilation strategies. ${ }^{12}$

Responding to the constraints of the supply chain, PT-D went back to the drawing board to address the problems of integrating an efficient MVHR system into the dwelling. Efficient MVHR requires large MVHR units and extensive ductwork with large cross-sectional areas. Dwelling D was a

12 This figure was developed in the context of the 2006 revision of Part L of the Building Regulations for England \& Wales, based on [59]. There are a number of important differences between the systems that are not captured in this graph, for example with respect to thermal comfort. Heat recovery is normally associated with MVHR, but other options exist. PT-E chose to add heat recovery to a mechanically assisted passive stack ventilation system. This system used the outgoing air as the heat source for a heat pump which, in parallel with a solar thermal system, preheated the water supply to a gas-fired combi-boiler. In practice, at current energy prices, this combination offers only modest cost savings. 
narrow, 3 storey terraced house, with a gross floor area of only $100 \mathrm{~m}^{2}$. However, with good communication between the PT and the occupants, some of the duct-work was successfully rerouted through a chimney breast (the terrace had been built around the middle of the $20^{\text {th }}$ Century when coal was still the main form of heating in UK dwellings) allowing the MVHR unit, with its bulky silencers, to be installed in the loft. The resulting re-arrangement of physical components made this new technology more acceptable to occupants who had initially been fearful of losing valuable storage space and of the likelihood of noise from such a large ventilation unit ${ }^{13}$. Although MVHR was the fallback choice, it turned out to be a good solution. The occupants liked it, and the overall performance of the retrofitted dwelling was good ${ }^{14}$.

\section{Problem-cascade triggered by radical retrofit strategy - Dwelling B}

Problems arising from the dynamics of heating and ventilation systems are best illustrated by the experiences of PT-B who fitted a communal heating system coupled to individual ventilation systems across a terrace of 4 dwellings. PT-B's reflection revealed that a series of micro-actions within the retrofit processes of this case were not well coordinated and were poorly supported by existing social (supply chain) infrastructure. PT-B articulated the problem of design and procurement changes and of a string of events that impacted on implementation as follows:

There was a last minute, not design change, but a product change. The original solar thermal heating was all designed to come from one supplier, and then there was a decision made to change part of it to a different supplier of solar thermal. That led to a lot of knock-on problems on site, with the compatibility of those two products. We had - the weather played a factor [...] and also when we did the plant room, there were problems in ground obstructions which we had to redesign, the slabs and foundations. [...] The critical delay was through the plant room getting a statutory [permission], so we could commission the plant room to get [gas] running. What happened, the sequence of events there [...] raised the slab to the plant room then we hit the really cold weather that prevented us doing all the blockwork [...] which then prevented us getting the services in so we couldn't call the stats [statutory undertakers, i.e. utilities] in to make the connections. Then, we got to a point where, the biggest problem was with the gas. They gave us a day, the $23^{\text {rd }}$ March, when they'd make the connections for the gas. [But] we did not get a gas supply in there until the $8^{\text {th }}$ July. They came to sign up on the $23^{\text {rd }}$, could not find a main, went away, came back two or three times in different locations, trying to find the main, which [they] didn't... We actually pulled off site for three months because we got as far as we could without getting any services in. The gas went live on the $8^{\text {th }} \mathrm{July}$, which, then we had to commission the systems and get them up and running, so, the changeover to the properties, to the new heating and hot water system didn't happen until the $14^{\text {th }}$ August.

${ }^{13}$ Generally, as well as being more efficient, larger ventilation systems are likely to be quieter, but the latter is likely to appear paradoxical to dwelling occupants.

${ }^{14}$ Gas consumption for dwelling D with a family of 8 is estimated to have been around 18,000 kWh a year before the retrofit, somewhat above the UK median of $16,500 \mathrm{kWh}$. After the retrofit, gas consumption was around $9,000 \mathrm{kWh}$ a year, indicating roughly a 50\% reduction. This represents a significant achievement, given the likely high demand for hot water heating with a family of 8 . 
It also transpired that the system had been put together by different suppliers and contractors. As a result, there was hardware incompatibility as well as difficulties in reconciling the controls of two different systems. The constructor continued:

The central controls, the way $\mathrm{V}$ [system manufacturer 1] dealt with the controls - they have a closed system that they use, whereas $M$ [system manufacturer 2] use an open source system. And had V used an open source system, half of the problems we've had would not have been [in] the situation. This was further compounded that, when M priced it, they priced it for a two-cylinder system, which was totally incompatible with control, with one cylinder. So then they had to go and source a new cylinder that came from Germany that had a three-week lead in. When that was delivered to site, because it was 1000 litres, it was classed as a commercial cylinder rather than a self-contained cylinder, so all the safety controls didn't come with it. So again, these had to be ordered specially, from Germany, and it just, just totally lost momentum, because we'd take one step forward, and another problem [came] along.

The resulting issues meant that the retrofit process lasted a year, and the heating/ventilation and hot water system did not work for many months. Occupants coped by using a variety of electric resistance heating systems, footing electricity bills which in some cases they could ill-afford.

The above illustrates the necessary converse of what was observed with respect to House D: that programmes of construction or reconstruction can be derailed by unexpected/emergent linkages between apparently unconnected aspects of the job, that seemingly insignificant changes to suppliers and specifications can render complex systems unbuildable or uncommissionable, and that delays compound, and test budgets, commitment and professionalism. Professionals who choose to venture beyond the routine and the everyday, can no longer rely on the practices of their professional communities, and inevitably run such risks.

\section{Discussion and conclusions}

The aim of this paper is not primarily to rehearse the difficulties of retrofitting existing dwellings, but by reflecting on the ways that PTs deal with these difficulties, to explore what this tells us about the usefulness of SPT for accounting for creativity. SPT is a heuristic device to provide an account of activities that form and are recognisable as repeated patterns that together constitute the social order. Examples of social practices include marriage and child-rearing, agricultural practices and practices associated with financial services (the last of these, extensively documented by Schatzki [26]). The set of construction practices itself is an accumulation of knowledge and skills, exercised in a largely technical context, and organised into repeated patterns, that support an industry requiring the precise coordination of dozens of specialised professions and trades and (merely in the UK) hundreds of thousands of people working at any one time on thousands of sites [61].

Retrofit for the Future was an experiment that challenged practitioners precisely to transcend existing practices, in order to develop new know-how and practical understanding to allow the integration of new and unfamiliar technology in technically indeterminate settings, in the context of 
explicit and implicit social rules relating to issues that ranged from interactions with neighbours, through heritage value to Building Regulations.

Analytically, in attempting to use SPT to provide an account of practices at this historical moment, it became clear that the theory was insufficient to support an investigation of innovation: the theory lacks the categories needed to allow the researcher to anticipate where innovation would occur, or to describe the processes that would be involved.

The purpose of the following discussion is to review those aspects of retrofit that fit within Social Practice Theory, with a view to identifying those that do not. This then allows us formulate a proposal for extending the SPT to embrace the latter. Our discussion is accordingly signposted with the four theoretical components of Schatzki's SPT: teleo-affective structures, practical understanding, rules and entities (human and non-human).

The PTs that undertook the retrofits investigated in the FLASH project had a common, albeit constructed purpose - to transform existing dwellings into highly energy efficient homes. By participating in this experiment, PTs voluntarily placed themselves in a competitive but indeterminate environment where the nature of the programme drove their ambition, initial formulation of retrofit strategies and desire to learn. Yet contextual and emerging complexity, combined with their commitment to the goals of the RftF Programme, forced them continually to re-think, negotiate, and innovate. This reflects the complex and shifting interplay of purpose and emotions (teleoaffectivity) and social, physical and technological constraints within which PTs operated.

PTs' know-how (practical understanding) and rules embedded in institutional, organisational and regulatory structures played important roles in their strategic planning and actions in the innovation process. For example, as a result of the heritage value of some dwellings, PTs were constrained in their choices of designs and materials applied (cases C, E \& G), by both implicit and explicit rules relating to heritage.

Retrofits were also constrained by explicit institutional rules encoded in Building Regulations. This is exemplified by the impact of Regulations on the insulation of floors through the need to adjust riser heights for stairs (e.g. PT-A and PT-D). With the right physical configuration and the adoption of a different insulation solution - running external insulation below ground level down to footings - these problems could be completely bypassed (PTs-B\&H); but this was not possible in all cases.

Implicit social rules could also be at play. PT-A's initial strategy (Passivhaus) had to be abandoned in the face of Dwelling A occupant's concern that her house would stand out among her neighbours' houses after retrofit. By implementing a hybrid wall insulation solution, PT-A was able to allay the occupant's concern while achieving the same thermal effect. Rules (social or physical) are enduring structures that govern human activities; without them the social world would be unintelligible, and our physical environment would be unmanageable. However, it is at the very moment that we discover these rules conflict with purpose, that creativity beckons. 
The PTs' design intentions could be seen as the pre-condition for such creativity, precisely because they were rarely implemented smoothly. PTs had to confront problems that emerged from the complex dynamics of the technological arrangements associated with modern retrofit, of which the interplay of fabric, heating and ventilation systems described in this paper provides an example. While simple technical rules-of-thumb (e.g. Figure 1) may in principle aid the choice of ventilation systems, in practice, the functioning and performance of such systems depend on coupling design, implementation and use, in the context of both social and physical and technological constraints, interactions of which cannot easily be handled by rules-of-thumb. PTs' failures and successes in implementing MVHR in their respective projects reflected this complex dynamic.

While institutional rules are often established to guide and simplify practice, it was the confrontation of routinised practice with unexpected physical and social constraints that gave rise to the impetus for creative responses. In the cases studied, the resulting tensions were all accommodated by the PTs. But in the longer term, one would also expect to see building regulations and other socio-technical governance infrastructure changing either to decrease uncertainty, or to accommodate the emerging requirements of retrofit technology and markets, and a maturing retrofit industry. In parallel with this, one would also expect to see the development of ready-made technological solutions that black-box a number of the problems with which the PT's engaged in the Retrofit for the Future Programme had consciously and explicitly to grapple.

One conclusion from the above is that technology (non-human entities) and physical rules play a significant, and sometimes dominant role in the context of retrofit. Researchers who wish to appropriate SPT to investigate retrofit activities as a form of social practice must keep in mind the need to understand physical systems, which are the unavoidable partners of the social in the dance of socio-technical evolution, in their own terms. Although there are signs that current energy research practice is changing, more effort is needed to build capacity for multi-disciplinary research and practical methods for evaluating built performance.

But more importantly, the above discussion shows that SPT is limited by its erasure of the human mind. The PTs' reflections on their experiences illustrate clearly why a theory of routinised practice is unable to account for creativity. Without restoring the ingenuity of the human mind, through the incorporation of the Pragmatists' concept of situated creativity into the conceptual framework of SPT, accounting for the processes of innovation as set out in this paper would be impossible.

\section{References}

1. Dewey J. The quest for certainty: a study of the relation of knowledge and action. New York: Putnam; 1929.

2. Palmer J. \& Cooper I. United Kingdom housing energy fact file. London: DECC; 2013. https://www.gov.uk/government/statistics/united-kingdom-housing-energy-fact-file-2013

3. Commission for Climate Change (CCC). UK housing: fit for the future? London; 2019. https://www.theccc.org.uk/wp-content/uploads/2019/02/UK-housing-Fit-for-the-future-CCC- 
2019.pdf

4. Ministry of Housing, Communities \& Local Government (MHCLG). English Housing Survey, Headline Report 2017-8. London; 2019.

5. Ministry of Public Building and Works. The Building Regulations. London; 1965.

6. HM Government. Construction 2025. London; 2013.

https://assets.publishing.service.gov.uk/government/uploads/system/uploads/attachment_data /file/210099/bis-13-955-construction-2025-industrial-strategy.pdf

7. BEIS. The Clean Growth Strategy: Leading the way to a low carbon future. London:

Department for Business, Energy \& Industrial Strategy; 2017.

https://www.gov.uk/government/publications/clean-growth-strategy

8. Committee on Climate Change (CCC). Reducing UK emissions: 2018 progress report to

Parliament. London; 2018. https://www.theccc.org.uk/publication/reducing-uk-emissions-2018progress-report-to-parliament/

9. Lowe, RJ. Technical options and strategies for decarbonizing UK housing, Build. Res. Inf. 2007: 35(4) 412-425. https://doi.org/10.1080/09613210701238268

10. BEIS. Clean Growth - Transforming Heating: Overview of Current Evidence. London; 2018 https://assets.publishing.service.gov.uk/government/uploads/system/uploads/attachment data ffile/766109/decarbonising-heating.pdf

11. Committee on Climate Change. Net Zero: the UK's contribution to stopping global warming. London; 2019. https://www.theccc.org.uk/publication/net-zero-the-uks-contribution-tostopping-global-warming/

12. Baregheh A, Rowley J \& Sambrook S. Towards a multidisciplinary definition of innovation. Manag Decis. 2009: 47(8) 1323-1339. https://doi.org/10.1108/00251740910984578

13. Rogers E. Diffusion of innovations. $5^{\text {th }}$ ed. Simon and Schuster; 2003.

14. BEIS. The UK Innovation Survey: Headline Findings 2014 to 2016. London; 2017. http://doc.ukdataservice.ac.uk/doc/6699/mrdoc/pdf/6699_ukis_2017_headlines_final.pdf

15. Eurostat. Concepts and Definitions Database - Innovation.

https://ec.europa.eu/eurostat/ramon/nomenclatures/index.cfm?TargetUrl=DSP_GLOSSARY_N OM DTL VIEW\&StrNom=CODED2\&StrLanguageCode=EN\&IntKey=16501035\&RdoSearch=B EGIN\&TxtSearch=innovation\&CboTheme $=\& I s T e r=\& I n t$ CurrentPage $=1 \&$ ter valid $=0$

16. Bordass W \& Leaman A. Future buildings and their services: Strategic considerations for designers and clients. Build. Res. Inf. 1997; 25(4) 190-195.

https://doi.org/10.1080/096132197370309

17. Cohen R, Standeven M, Bordass, W \& Leaman A. Assessing building performance in use 1: the Probe process. Build. Res. Inf. 2001; 29(2):103-13. https://doi.org/10.1080/09613210010008018

18. Chiu LF, Lowe R, Raslan R, Altamirano-Medina H \& Wingfield J. A socio-technical approach to post-occupancy evaluation: interactive adaptability in domestic retrofit. Build. Res. Inf. 2014: 42(5) 574-590. https://doi.org/10.1080/09613218.2014.912539 
19. Lowe R, Chiu LF, Oreszczyn T. Socio-technical case study method in building performance evaluation. Build. Res. Inf. 2018; 46(5) 469-484. https://doi.org/10.1080/09613218.2014.912539

20. Baborska-Narozny M., Stevenson F \& Ziyad F. User learning and practices in relation to innovative technologies: a case study of domestic photovoltaic systems. Energy Res. Soc. Sci. 2016; 13: 24-37. https://doi.org/10.1016/j.erss.2015.12.002

21. Joas H. Pragmatism and social theory. Chicago \& London: University of Chicago Press; 1993.

22. Baert P. Philosophy of social sciences: Towards Pragmatism. Cambridge: Polity Press; 2005.

23. Schön D. The reflective practitioner: how professionals think in action. New York: Basic Books; 1983.

24. O'Ca D, Chen C, Hong T \& Belafi Z. Synthesizing building physics with social psychology An interdisciplinary framework for context and occupant behaviours in office building. Energy Res. Soc. Sci. 2017; 34: 240-251. https://doi.org/10.1016/j.erss.2017.08.002

25. Schatzki TR. Social practices: A Wittgensteinian approach to human activity and the social. Cambridge: Cambridge University Press; 1996.

26. Schatzki TR. The site of the social: a philosophical account of the constitution of social life and change. University Park, PA: Pennsylvania State University Press; 2002.

27. Schatzki TR. Introduction. In: Schatzki T.R., Cetina K.K., von Savigny E., editors. The practice turn in contemporary theory. London: Routledge; 2001.

28. Wilhite H. The conditioning of comfort. Build. Res. Inf. 2009; 37(1) 84-8. https://doi.org/10.1080/09613210802559943

29. Gronow J \& Warde A. Ordinary consumption. 2001; New York: Psychology Press.

30. Gram-Hanssen K. Residential heat comfort practices: understanding users. Build. Res. Inf. 2010; 38(2) 175-86. https://doi.org/10.1080/09613210903541527

31. Strengers Y. Negotiating Everyday Life: The role of energy and water consumption feed-back. J. Consum. Cult. 2011; 11(3) 319-38. https://doi.org/10.1177/1469540511417994

32. Butler C, Parkhill KA., \& Pidgeon NF. Energy consumption and every-day life: choice values and agency through a practice theoretical lens. J. Consum. Cult. 2014; 16: 887-907. https://doi.org/10.1177/1469540514553691

33. Gram-Hanssen, K. Understanding change and continuity in residential energy consumption. J. Consum. Cult. 2011; 11(1) 61-78. https://doi.org/10.1177/1469540510391725

34. Royston, S. Dragon-breath and snow-melt: know-how, experience and heat flows in the home. Energy Res. Soc. Sci. 2014; 2:148-58. https://doi.org/10.1016/j.erss.2014.04.016

35. Day R. \& Hitchings R. "Only old ladies would do that": age stigma and older people's strategies for dealing with winter cold. Health Place. 2011;17(4) 885-94.

https://doi.org/10.1016/j.healthplace.2011.04.011

36. Jalas M \& Rinkinen J. Stacking wood and staying warm: time temporality and housework around domestic heating systems. J. Consum. Cult. 2012; 11:61-78.

https://doi.org/10.1177/1469540513509639 
37. Tweed C. Socio-technical issues in dwelling retrofit. Build. Res. Inf. 2013; 41(5) 551-62. https://doi.org/10.1080/09613218.2013.815047

38. Karvonen A. Towards systemic domestic retrofit: A social practices approach. Build. Res. Inf. 2013; 41(5) 563-574. https://doi.org/10.1080/09613218.2013.805298

39. Baborska-Narozny M., Stevenson F. \& Grudzinska M. Overheating in retrofitted flats: occupant practices, learning and intervention. Build. Res. Inf. 2017; 45 (1-2) 40-59. https://doi.org/10.1080/09613218.2016.1226671

40. Gram-Hanssen K. Residential heat comfort practice: understanding users. Build. Res. Inf. 2010; 38 (2) 175-176. https://doi.org/10.1080/09613210903541527

41. Madsen LV. The comfortable home and energy consumption. Hous. Theory Soc. 2018; 35(3) 329-52. https://doi.org/10.1080/14036096.2017.1348390

42. Baborska-Narozny $M, \&$ Stevenson F. Mechanical ventilation in housing; Understanding in-use issues. Proc. Institution of Civil Engineers - Engineering sustainability. 2017; 170 (1) 33-46. https://doi.org/10.1680/jensu.15.00053

43. Rouse J. Engaging science: how to understand its practices philosophically. Ithaca: Cornell University Press; 1996.

44. Pickering A. The mangle of practice: time, agency, and science. Chicago \& London: Chicago University Press; 1995.

45. Pickering A. Practice and post-humanism: Social history and a history of agency. In Schatzki TR, Cetina KK, Von Savigny E, editors. The practice turn in contemporary theory. Routledge; 2001. p.172-183.

46. Forester J. On the theory and practice of critical pragmatism: Deliberative practice and creative negotiations. Planning Theory. 2012; 12(1) 5-22. https://doi.org/10.1177/1473095212448750

47. Gross N. A Pragmatist theory of social mechanisms. Am. Soc. Rev. 2009; 74(3) 358-79. https://www.jstor.org/stable/27736068

48 Whitehead AN. An Introduction to Mathematics. New York: Henry Holt \& Co. London: Williams and Norgate; 1911.

49 Schumpeter JA. The creative response in economic history, The Journal of Economic History 1947; 7(2) 149-159. Cambridge University Press on behalf of the Economic History Association. https://www.jstor.org/stable/2113338

50 Kuhn TS. The Structure of Scientific Revolutions. Chicago \& London: University of Chicago Press; 1962.

51 Newell A, Shaw JC. \& Simon HA. Elements of a Theory of Human Problem Solving, Psychological Review, 1958; 65: 151-166. http://dx.doi.org/10.1037/h0048495

52 Newell A \& Simon HA. Human Problem Solving. NJ: Prentice-Hall; 1972.

53. Taalbi J. What drives innovation? Evidence from economic history. Research Policy 2017; 46 (8) 1437-1453. https://doi.org/10.1016/j.respol.2017.06.007

54. Chiu LF. Critical reflection: More than nuts and bolts. Action Res. 2006; 4:183-203. 
https://doi.org/10.1177/1476750306063991

55. Rosenow J \& Eyre N. A post mortem of the Green Deal: austerity, energy efficiency, and failure in British energy policy. Energy Res. Soc. Sci. 2016; 21:141-144.

https://doi.org/10.1016/j.erss.2016.07.005

56. National Audit Office. Green Deal and Energy Company Obligation, HC 607 Session 2015-16 14 April 2016. London: 2016. https://www.nao.org.uk/wp-content/uploads/2016/04/GreenDeal-and-Energy-Company-Obligation.pdf

57. Lowe, RJ, Chiu, LF, Raslan, R \& Altamirano, H. Retrofit insights: perspectives for an emerging industry. UCL-Energy for Institute for Sustainability; 2012.

58. Carlsson B, Elmroth A \& Engvall PA. Airtightness and thermal insulation: building design solutions. Stockholm: Statens Råd för Byggnadsforskning; 1980.

59. Lowe RJ. Ventilation, energy use and $\mathrm{CO}_{2}$ emissions in dwellings - a theoretical approach, Build. Serv. Eng. Res. \& T. 2000: 21 (3) 181-187.

http://www.aivc.org/sites/default/files/airbase 13392.pdf

60. Harvey LD. Energy and the new reality 1: energy efficiency and the demand for energy services. Abingdon: Routledge; 2010.

61. Brockmann, M, Clarke, L \& Winch, C, with Hanf, G, Méhaut, P \& Westerhuis, A. Knowledge, Skills and Competence in the European Labour Market. Abingdon: Routledge; 2011. 